\title{
Localization of the pathogen Vibrio P1 in clams affected by Brown Ring Disease
}

\author{
B. Allam, C. Paillard*, P. Maes
}

URA CNRS D1513, Institut Universitaire Européen de la Mer, Université de Bretagne Occidentale, F-29287 Brest Cedex, France

\begin{abstract}
Since 1987, Brown Ring Disease, caused by a bacterial pathogen named Vibrio P1 (VP1), has spread throughout aquacultural sites for the manila clam Ruditapes philippinarum along the French Atlantic coast. Experimental pathology revealed that the heterotrophic bacterial microflora increased during the development of the disease and VP1 levels remained relatively stable. The greatest proportion of VP1 bacteria was associated with the surface of the clam flesh. Surface bacteria represented about $90 \%$ of the VP1 amount in experimentally diseased clams. Similarly, the mantle did not seem to be deeply colonized by VP1, since an alcohol rinse precluded detection of the pathogen by bacteriological methods. Microscopic observations of heavily diseased clams also revealed that VP1 is particularly associated with the periostracal lamina. The possibility of any other major site of infection can be eliminated.
\end{abstract}

KEY WORDS: Bivalve - Ruditapes philippinarum - Shell disease Periostracal lamina - Bacteria Immunofluorescence

\section{INTRODUCTION}

The manila clam Ruditapes philippinarum has been imported into France since 1972 for aquacultural purposes. This new venerid culture became increasingly widespread up to 1986 . Since this time, mass mortalities in manila clam beds have occurred, associated with Brown Ring Disease (BRD) (Paillard et al. 1989). This disease is characterized by an abnormal deposit of conchiolin on the inner surface of the valves, between the pallial line and the edge of the shell (Paillard et al. 1989, Paillard 1992). A Vibrio sp., subsequently called Vibrio P1 or VP1, was isolated and defined as the etiological agent (Paillard \& Maes 1990, Maes 1992). Bacteria of the Vibrio genus had previously been associated with bivalve larval mortalities (Tubiash et al. 1965, 1970, Le Pennec \& Prieur 1977, Elston \& Leibovitz 1980, Nottage et al. 1989). To our knowledge, however, BRD along with the Pacific Oyster Nocardiosis (Friedman \& Hedrick 1991, Friedman et al. 1991) are the only demonstrated bacterial diseases affecting adult bivalves (Paillard \& Maes 1990, Paillard et al. 1994).

•E-mail: paillard@univ-brest.fr
A detailed description of BRD development has recently been proposed by Paillard \& Maes (1994). These authors demonstrated the cyclic and chronic character of the disease and established a classification system that accounts for the extent, location and thickness of the conchiolin deposit. A shell repair process was described which consists of deposition of new calcified layers by the mantle epidermis over the conchiolin deposit.

It has already been demonstrated that VP1 disrupts the clam's normal calcification process by adhering to the periostracal lamina and decomposing it (Paillard 1992, Pallard \& Maes 1995a). This alteration provokes the deposition and accumulation of the periostracal lamina on the inner surface of the shell, thereby producing the conchiolin deposit (Paillard et al. 1994, Paillard \& Maes 1995a, b). Plana \& Le Pennec (1991) observed alterations in the digestive diverticula which degenerates in experimentally diseased clams, and bacterial bodies have also been observed in the digestive cells of infected clams (Plana 1995). In addition, VP1-contaminated clams exhibit a disruption of their immune system as indicated by a decrease in circulating hemocyte concentrations and serum aminopep- 
tidase specific activity (Oubella et al. 1993, 1994). To date, tissue infection by VP1 has never been described.

The aim of this study was to identify the location of the pathogen in the tissues, secretions and shell cavity fluid of diseased clams. Two methods were used: (1) bacteriology, to evaluate bacterial proliferation during the development of BRD in experimentally infected clams, and (2) microscopic detection of Vibrio P1 by mean of immunofluorescence techniques.

\section{MATERIALS AND METHODS}

Samples. Healthy juvenile manila clams Ruditapes philippinarum (10 to $15 \mathrm{~mm}$, showing no signs of BRD syndrome) were obtained from hatcheries. Diseased adult clams (30 to $40 \mathrm{~mm}$ ) were collected from clam beds in Brouennou (Landeda, North Finistere, France) in May 1994. Clams were maintained unfed throughout experiments in aerated marine aquaria at $15 \pm 1^{\circ} \mathrm{C}$. Vibrio P1 strain was isolated from diseased clams. Other Vibrio strains were isolated from diseased clams and subjected to immunofluorescence techniques.

Infection experiment. An infection experiment was performed according to Paillard \& Maes $(1990,1994)$. A VP1 suspension of $10^{8}$ cells $\mathrm{ml}^{-1}$ in sterile seawater (SSW) was obtained from a 72 h culture grown on marine agar. A volume of $0.1 \mathrm{ml}\left(10^{7}\right.$ bacteria) from this suspension was inoculated into the pallial cavity of each experimental juvenile clam without damaging the shell. Experimental and control (non-inoculated) clams were left out of water for $8 \mathrm{~h}$, and then placed in separate aquaria. Surrounding water was changed weekly after sample collection. Twenty clams were sampled at each time interval (time zero, $8 \mathrm{~h}, 1,3,7,14$, 28,46 and 72 d for contaminated clams, and time zero, 8,28 and 46 d for controls) and used for bacteriological (10 clams per sample) and histo-immunological analyses (10 clams per sample). Disease progression was monitored on the clams analysed for bacteriology.

Bacteriology. The external shell surface of 10 clams was washed by scrubbing under running tap water to remove mud and marine life, sprinkled with $70 \%$ ethanol and allowed to dry. Clams were then opened aseptically by cutting the adductor muscles with a sterile knife. The shell cavity fluid (all the running fluid when clams are opened which contains mainly pallial fluid, some peripheral extrapallial fluid and hemolymph bled from adductor muscles) from 2 groups of 5 specimens was extracted and pooled. The tissues of the first group were washed with SSW, transferred to a sterile plastic jar and weighed. The tissues of the second group were immersed in absolute ethanol for a few seconds in order to remove surface bacteria and then rinsed with SSW. For the last sampling interval (72 d after contamination), the mantle was surgically separated from the rest of the flesh before the different rinses. For each of the sampling intervals, the tissues were blended for $30 \mathrm{~s}$ in SSW $(1 / 10 ; \mathrm{w} / \mathrm{v})$ using a Polytron $^{T M}$ blender, and serial dilutions of the homogenates were prepared in SSW. A volume of $0.1 \mathrm{ml}$ of both the diluted homogenates and the shell cavity fluid was plated on marine agar $[1 \mathrm{l}$ distilled water, $15 \mathrm{~g}$ agar, $20 \mathrm{~g}$ sea salts (Sigma), $4 \mathrm{~g}$ peptone, $0.1 \mathrm{~g} \mathrm{Fe}\left(\mathrm{PO}_{4}\right)_{2}$ ] and incubated for $72 \mathrm{~h}$ at $20^{\circ} \mathrm{C}$ to determine total heterotrophic bacterial microflora (THBM). Isolation of VP1 was performed according to Maes (1992). Briefly, replicate subcultures were used for testing 4 VP1 key characteristics: non-utilisation of sucrose and mannitol, growth on TCBS (thiosulfate citrate bile sucrose), and failure to grow above $28^{\circ} \mathrm{C}$. The colonies meeting these 4 requirements were purified and subjected to a slide agglutination test using rabbit anti-VP1 serum.

Results of bacterial counts are presented as colony forming units per $\mathrm{ml}$ (shell cavity fluid; $\mathrm{cfu} \mathrm{m}^{-1}$ ) or per $g$ wet weight (soft tissues; $\mathrm{cfu} \mathrm{g}^{-1}$ ). The term 'superficial' bacteria $\left(\mathrm{THBM}_{\mathrm{S}}\right.$ or $\mathrm{VP} 1_{\mathrm{S}}$ ) refers to the difference between the amounts of bacteria (THBM or VP1) detected in SSW-rinsed flesh and in ethanol-rinsed flesh which should represent only those bacteria within the tissues ('tissue' bacteria).

Histological methods. Clams sampled for histoimmunological analyses were fixed with their shells in fresh aqueous Bouin's solution for 48 h or longer. With the use of a binocular microscope, decalcified shells were then carefully removed in such a way as to preserve the structural integrity of the animal tissues. The flesh samples were dehydrated in graded ethanol and xylene series, and embedded in paraffin. Paraffin sections (5 $\mu \mathrm{m}$ thick) were used for immunofluorescence treatments and for Masson's trichrome staining (Gabe 1968). Additional samples were embedded in resin (hydroxyethylmethacrylate activated by benzol peroxide and dimethyl sulfoxyde) to obtain thinner sections ( 2 to $3 \mu \mathrm{m}$ thick), which were dyed with toluidine blue (Gabe 1968) or subjected to the immunofluorescence technique.

Immunofluorescence. An indirect immunofluorescence method using an anti-VP1 rabbit serum was used to identify VP1 in tissue sections, periostracal lamina and conchiolin deposit fragments. The antiVP1 serum was supplied by the Institut Pasteur (Paris, France). The slides were rinsed in $0.1 \mathrm{M}$ phosphatebuffered solution (PBS, pH 7.4) and covered for $30 \mathrm{~min}$ at room temperature with a normal-goat serum $120 \%$ in PBS). The primary antibody (rabbit anti-VP1, $0.5 \%$ in PBS) was applied to the histological sections and carried out in a moist chamber for $1 \mathrm{~h}$ at $30^{\circ} \mathrm{C}$. Sections were then covered by fluorescein isothiocyanateconjugated goat anti-rabbit antibody [secondary anti- 
body, diluted in PBS (1\%) containing 1\% bovine serum albumin] for $45 \mathrm{~min}$ at $30^{\circ} \mathrm{C}$ in the dark. The preparations were then rinsed 3 times with PBS and mounted in non-fluorescent microscopic oil before examination under an Olympus ${ }^{\mathrm{TM}}$ microscope equipped with epifluorescence illumination and using a 450-490 nm exciter-barrier filter and reflector combination. About 100 histological sections were processed of 5 to 10 clams per sample. In parallel, smears of both VP1 and other Vibrio sp. strains phenotypically different from VP1 and abundant in diseased clams were subjected to the same treatments to constitute positive and negative controls respectively.

Statistical analysis. Parametric (Student's t-test) and non-parametric tests (Wilcoxon's signed-ranks test) were used to examine bacteriological results. As no remarkable differences in the bacterial counts were noted between the shell cavity fluid subsamples ( 2 pools of a same sample), the mean bacterial count for each sample is represented. Student's test was applied on these counts $(n=2)$ converted to $\log _{10}$ by assuming that $\log _{10}$ bacterial counts in the shell cavity fluid have a normal distribution and by taking into account the hypothesis of unequality of variances. Significance levels were noted for each comparison.

\section{RESULTS}

\section{Bacterial count}

\section{Controls}

Total heterotrophic bacterial microflora (THBM) levels were checked in the shell cavity fluid (Fig. 1) and the flesh (Fig. 2) of uninjected control clams. They remained relatively stable $\left(1\right.$ to $3.6 \times 10^{4} \mathrm{cfu} \mathrm{m}^{-1}$ in the shell cavity fluid and 1 to $5 \times 10^{5} \mathrm{cfu} \mathrm{g}^{-1}$ in the flesh) over a period of more than $6 \mathrm{wk}$. The pathogen (VP1) was never detected in control clams.

\section{Contaminated clams}

Shell cavity fluid. The inoculation of VP1 caused an immediate increase in the bacterial levels (Fig. 1). After $8 \mathrm{~h}$, the bacterial levels (VP1 and THBM) corresponded approximately to the number of bacteria inoculated into the clams (about $10^{7} \mathrm{cfu} \mathrm{m}^{-1}$ ). These levels decreased dramatically once the clams were placed in sea water.

THBM in infected clams attained $3 \times 10^{4} \mathrm{cfu} \mathrm{m}^{-1}$ after $1 \mathrm{~d}$, and increased slowly to reach $1.5 \times 10^{6} \mathrm{cfu}$ $\mathrm{ml}^{-1}$ at Day 46 (50 times control value, Fig. 1). In fact, THBM values were significantly higher in challenged

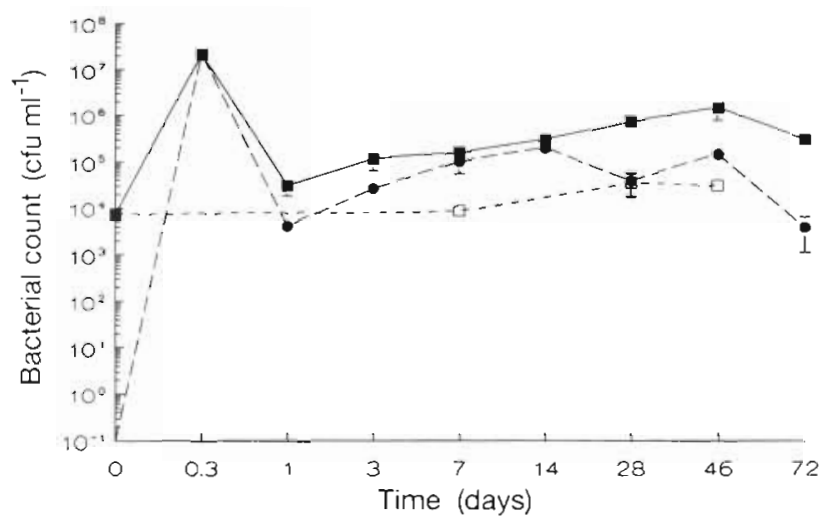

Fig. 1 Ruditapes philippinarum. Bacterial count in the shell cavity fluid. Mean \pm standard deviation (each point represents 2 pooled subsamples of 5 clams each). (-) THBM in challenged clams; (•) VP1 in challenged clams; (ㅁ) THBM in control clams

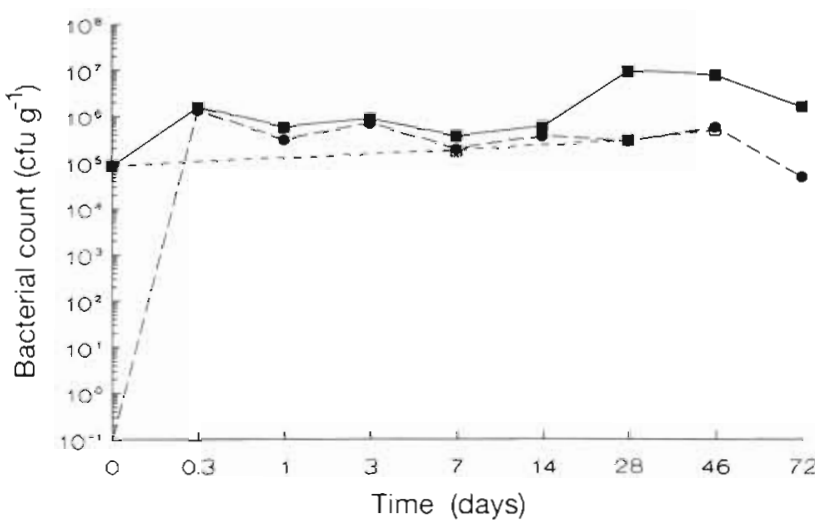

Fig. 2. Ruditapes philippinarum. Bacterial count in the flesh. Each point represents 5 pooled clams. (a) THBM in challenged clams; (•) VP1 in challenged clams; (a) THBM in control clams

than in control clams collected at Day $7(p=0.0015)$, Day $28(p=0.0095)$ and Day $46(p=0.0043)$ (Student's 1-tailed test), A slight decrease was observed after $72 \mathrm{~d}$ of incubation.

VP1 in infected clams attained $4.2 \times 10^{3} \mathrm{cfu} \mathrm{ml}^{-1}$ after $1 \mathrm{~d}$ and increased slowly to reach $2 \times 10^{5} \mathrm{cfu} \mathrm{m}^{-1}$ at Day 14 (Fig. 1). A significant decrease ( $p=0.01$, Student's 1 -tailed test) was observed after $72 \mathrm{~d}$ of incubation (37 times lower than the level detected at Day 46). VP1 and THBM reached their maximal levels on Days 14 and 46 respectively.

Flesh. An increase in THBM following challenge was observed (Fig, 2). No remarkable decrease in numbers was observed once the clams were placed in sea water. The THBM was relatively stable until Day $14\left(6 \times 10^{5}\right.$ cfu $\mathrm{g}^{-1}$ ), after which a substantial increase was observed up until Day 28 (32 times control value). A decrease in bacterial numbers was observed on Day 72. 
Total concentrations of VP1 for infected clams reached values similar to those observed for THBM following challenge (Fig. 2). Once the clams were placed in sea water, VP1 levels stabilized and remained at relatively constant levels until Day 46 ( 2 to $7 \times 10^{5} \mathrm{cfu} \mathrm{g}^{-1}$ ) after which a substantial decrease was observed on Day 72. Values on this last day were 13 times lower than those recorded on Day 46 (Fig. 2).

\section{Development of the brown ring deposit and mortality}

The development of the disease was also followed in the experimentally infected clams (Table 1). Several brown spots appeared on the inner face of the valves after Day 3 (microscopic sign). These spots became enlarged and were visible to the naked eye after $7 \mathrm{~d}$ of incubation. A well-developed brown ring, made up of several layers, was visible after $28 \mathrm{~d}$. Recalcification was observed in only 1 clam (out of 10) on Day 46 and was more frequent on Day 72 ( 7 out of 10 clams). Low mortality was observed after Day $3(3 \%)$; it increased progressively to finally reach $21 \%$ by Day 72 . In controls, the mortality level was low $(\leq 6 \%)$, and signs of disease were never observed.

Table 1. Ruditapes philippinarum. Development of the brown ring deposit and cumulative mortality in experimentally infected clams. ND: no data, $n=10$ clams per sample

\begin{tabular}{|crrrrr|}
\hline & \multicolumn{5}{c|}{ Time (d) } \\
& 3 & 7 & 28 & 46 & 72 \\
\hline $\begin{array}{l}\text { Brown Ring Syndrome (\%) } \\
\quad \text { Contaminated clams }\end{array}$ & 20 & 70 & 90 & 100 & 100 \\
$\quad$ Controls & 0 & 0 & 0 & 0 & 0 \\
$\begin{array}{l}\text { Recalcification (\%) } \\
\quad \text { Contaminated clams }\end{array}$ & 0 & 0 & 0 & 10 & 70 \\
$\begin{array}{l}\text { Mortality (\%) } \\
\quad \text { Contaminated clams } \\
\quad \text { Controls }\end{array}$ & 3 & 4.5 & 8.5 & 16.5 & 21 \\
& 2 & 3 & 4.5 & 6 & ND \\
\hline
\end{tabular}

\section{Localization of VP1}

Bacteriology

Until Day 14, the pathogen constituted more than $30 \%$ of the THBM of the flesh (Fig. 3). This proportion tended to decrease with the development of the disease. Superficial bacteria were predominantly VP1 (Fig. 3), fluctuating between 60 and $85 \%$ until Day 14 VP1/THBM ratios in the flesh had approximately similar trends for tissue and superficial bacteria with values consistently higher for the superficial bacteria ( $p=$

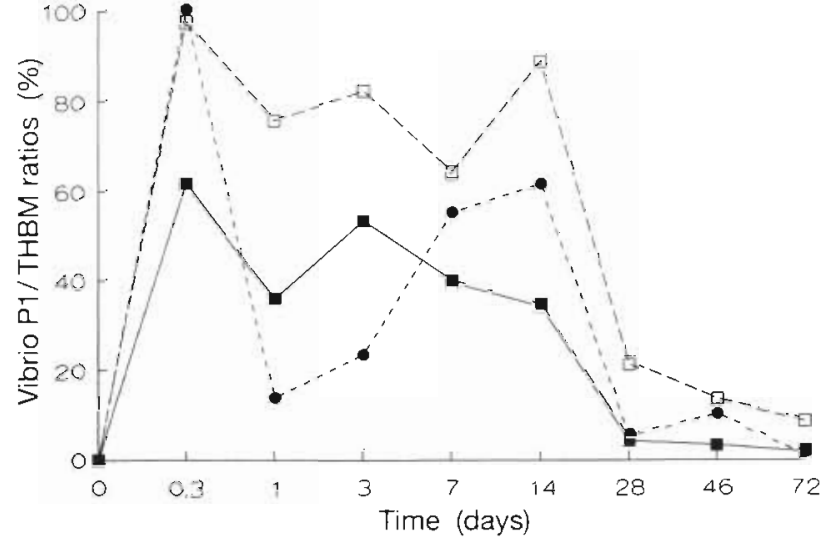

Fig. 3. Ruditapes philippinarum. VP1/THBM ratio in challenged clams. (ロ) Tissue bacteria; (ם) superficial bacteria; (•) shell cavity fluid

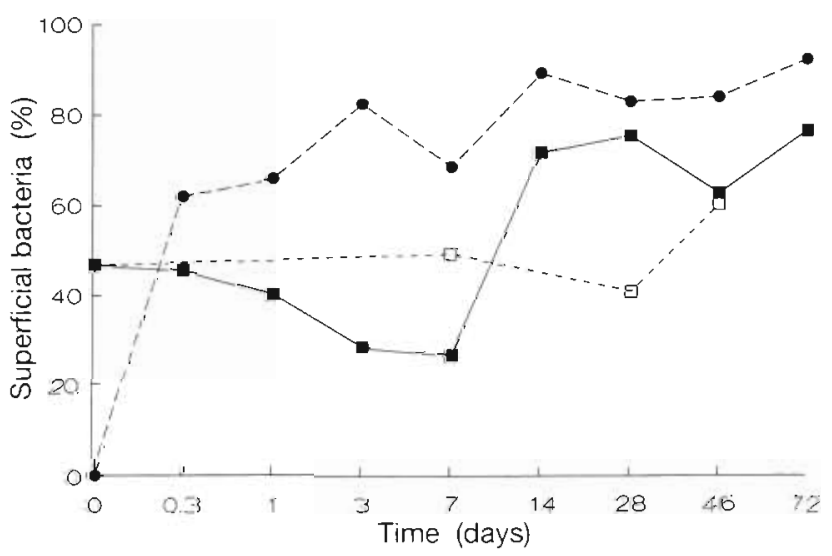

Fig. 4. Ruditapes philippinarum. Percentage of superficial bacteria compared to total. ( THBM $_{\mathrm{S}} / \mathrm{THBM}$ in challenged clams; $(\bullet)$ VP1 $1_{\mathrm{S}} / \mathrm{VP} 1$ in challenged clams; () THBM $/$ THBM in controls

0.013, Wilcoxon's signed-ranks test). The VP1/THBM ratio of the shell cavity fluid decreased sharply once the clams were placed in sea water but increased again to a maximal level on Day 14 . The development of bacterial microflora (other than VP1) brought about a substantial decrease in the VP1/THBM ratios of the flesh and the shell cavity fluid from Day 14 until the end of the experiment (Fig. 3).

The greatest proportion of detected VP1 bacteria was associated with the flesh surface (Fig. 4). These surface bacteria represented almost $90 \%$ of total VP1 amounts after Day 14. Percentage of superficial VP1 was consistently higher than that of THBM $(p=0.013$, Wilcoxon's signed-ranks test). Analysis of the mantle tissue (conducted on Day 72 ) revealed that no VP1 was detected after rinsing with alcohol (Fig. 5). In addition, the VP1 level in the remaining flesh (without mantle) 


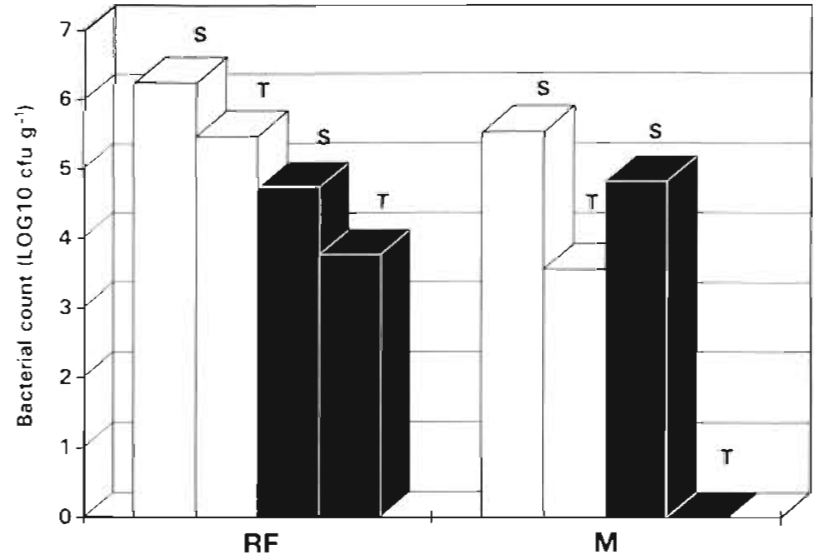

Fig. 5. Ruditapes philippinarum. Bacterial count in clams analysed $72 \mathrm{~d}$ after contamination. Black bars: VP1; white bars: THBM. M: mantle; RF: remaining flesh; $S$ : superficial bacteria; $T$ : tissue bacteria

\section{DISCUSSION}

Bacterial adhesion represents one of the first steps in the colonization of tissues (Arbuthnott \& Smith 1977). The relationship between adhesion and pathogenicity has already been established (Rogers 1977, Ijjima et al. 1981). It is dependent upon a certain specificity between the bacteria and the tissue surfaces they colonize (Rogers 1977, Smith 1977, Bartkova \& Ciznar 1992, Chen \& Hanna 1992). The association of vibrios with periostracum has already been reported in oysters and clams (Elston et al. 1982). Organic matrix colonization by bacteria is observed in the case of 'hinge ligament erosion' affecting juvenile oysters. These bacteria, identified as Cytophaga sp., penetrate and proliferate into the resilium and use this matrix as a growth substrate (Dungan \& Elston 1988, Dungan et al. was relatively low, being on the order $6 \times 10^{3}$ cfu $\mathrm{g}^{-1}$ or about 1200 bacteria per clam (mean of mantle-free flesh wet weight $\leq 0.2 \mathrm{~g}$ at Day 72).

\section{Microscopic detection of the pathogen}

Specificity of the serum. Five Vibrio spp. phenotypically different from VP1 were used to test the specificity of the anti-VP1 rabbit serum. A very faint fluorescence was detected on the smear of one of these bacterial strains. The other Vibrio spp. presented no detectable fluorescence. In addition, VP1 was easily detectable due to the localization of an intense fluorescence at the level of the bacterial membrane, forming a halo around the bacteria. No fluorescence was detected when the primary antibody was omitted.

Microscopic observations. Eight hours following challenge, VP1 was observed adhering to the surface of the periostracal lamina (Fig. 6) and the mantle and was also present within the digestive tract. After $24 \mathrm{~h}$ of incubation, VP1 was consistently detectable only on and within the periostracal lamina. Immunological detection techniques applied to fragments of the periostracal lamina and the conchiolin deposit revealed the presence of numerous VP1 cells and abundant nonidentifiable material (Fig. 7). Similar observations were obtained from diseased clams sampled from contaminated clam beds. The pathogen was never detected in control clams.

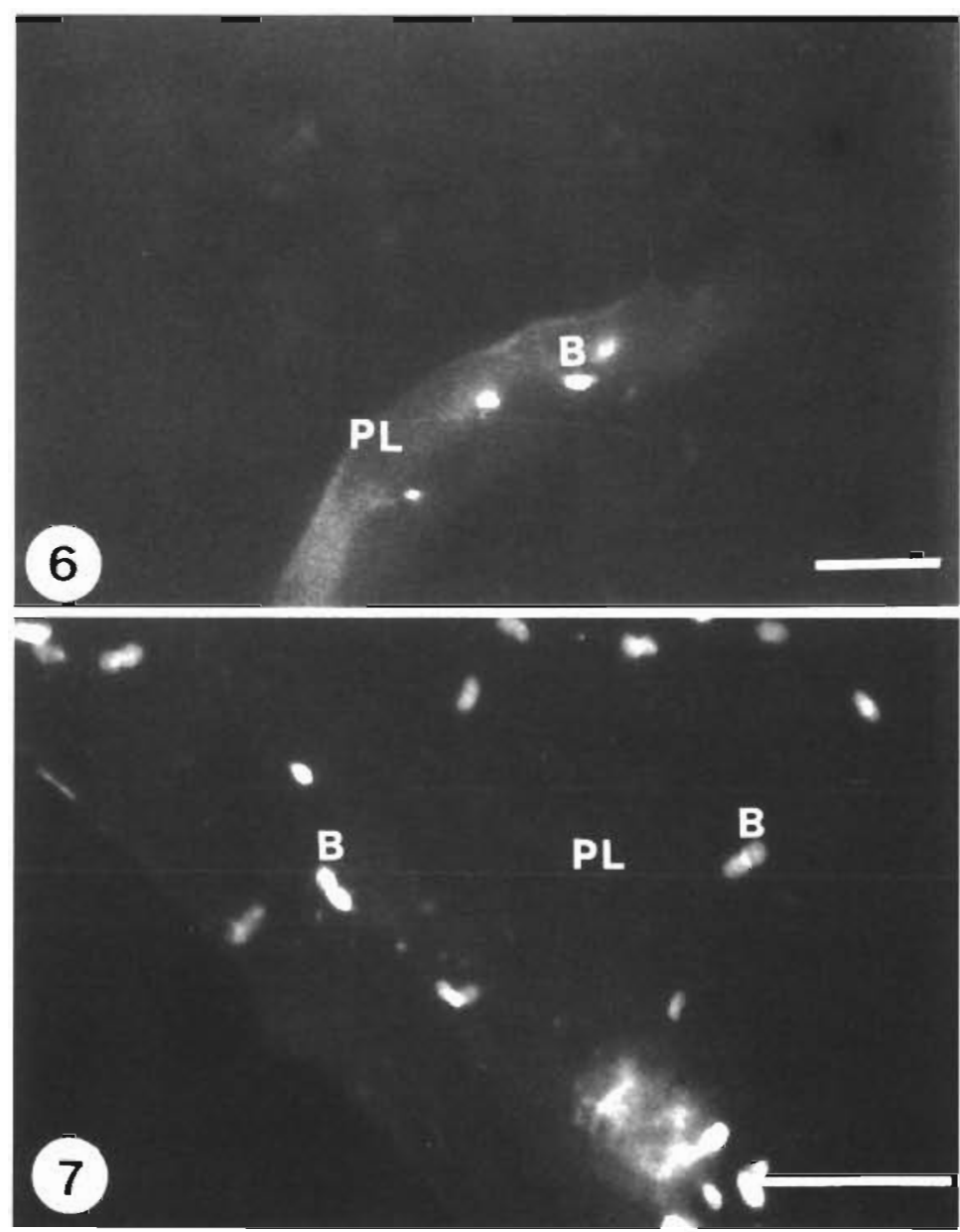

Figs. 6 \& 7. Vibrio P1 infecting Ruditapes philippinarum. Microscopic detection of the pathogen (indirect immunofluorescence technique). Fig. 6. Adhesion of VP1 to the periostracal lamina $8 \mathrm{~h}$ after contamination (thin sections). Fig. 7. VP1 adhering to fragments of the periostracal lamina 28 d after contamination. PL: periostracal lamina; $B$; bacteria. Scale bar $=10 \mu \mathrm{m}$ 
1989). Our results reveal that the pathogenic agent VP1 adheres to the surface of the periostracal lamina shortly after inoculation ( $8 \mathrm{~h}$ ) and remains present throughout the development of the disease. The brown conchiolin deposit, from the onset of its formation, is also heavily colonized by the pathogen. These represent the 2 sites where VP1 is regularly detected by the immunofluorescence technique. The results of the present study confirm those of Paillard (1992) and Paillard \& Maes (1995a, b), who observed, by means of scanning electronic microscopy and immunofluorescence, VP1 adhering to the periostracal lamina $12 \mathrm{~h}$ after inoculation, and who also described non-identifiable bacteria colonizing the lamina and the deposit after extended incubation.

The bacteriological results agree with those obtained microscopically and demonstrated that the majority of the VP1 cells were associated with the surface of the tissues and their numbers in the different clam compartments (shell cavity fluid and flesh) remained relatively stable throughout the development of the disease. This result could be linked to a bacterial saturation of the periostracal lamina, the major site of infection, during the first days of infection. The lamina and the deposit, which are heavily colonized by VP1, could regularly liberate bacteria into the pallial cavity fluid. These liberated bacteria could then be ingested, which would explain their presence in the flesh. Pathogen levels in clams may have been underestimated because a portion of the lamina and the entire brown deposit remain fixed to the shell during tissue sampling. Paillard (1992) and Paillard \& Maes (1995b) observed VP1 adhering to the mantle. However, the results of the present study indicate that the mantle is not deeply colonized as the pathogen is not detected in this tissue following alcohol rinsing.

Recently, VP1 has been occasionally observed, using the immunogold technique, inside altered digestive cells (Plana 1995). This was explained as serious alterations of cell membrane in highly diseased (moribund) clams that allowed bacteria (VP1 and other) to penetrate inside the cells. In our study, the failure to detect tissue VP1 microscopically during the development of the disease is a consequence of the relatively low levels present there 10 to $20 \%$ of total levels after Day 14), which correspond to about 1200 bacteria per clam at Day 72. Moreover, superficial VP1 was essentially localized on and within the periostracal lamina since microscopic detection was consistently successful only for this site. These results support the periostracal lamina being the only major site of infection.

The development of the brown ring symptom is accompanied by an increase in the total heterotrophic bacterial microflora (THBM other than VP1) which brings about a decrease in the VP1/THBM ratios.
These results confirm those of Maes (1992), who observed an increase in the number of THBM in diseased clams. In parallel, Paillard (1992) noted the presence of a multitude of variously shaped bacteria and fungal hyphae on the organic deposit. The phenomenon of recalcification, which consists of covering the conchiolin deposit with calcified layers (Paillard 1992, Paillard \& Maes 1994), may explain the decrease in levels of THBM and VP1 towards the end of the experiment. Indeed, Paillard et al. (1994) recently suggested that the formation of the brown melanized deposit constitutes one of the first steps of an external defence system which embeds the bacteria (VP1 in particular) and which secondarily leads to a complete covering of the abnormal organic deposit with new calcified layers. In addition, it would seem that mortality, which was relatively high at the end of the experiment, produces selection of the more resistant clams, which brings about an improvement in the average health of the clams and lower bacterial numbers. However until the surviving clams and their progeny are tested, this point is highly speculative.

In conclusion, our results indicate that the majority of the VP1 cells are localized at the tissue surface and, more precisely, on and within the periostracal lamina. It would therefore appear that the digestive gland changes observed by Plana \& Le Pennec (1991) in heavily diseased clams are not directly caused by VP1. This hypothesis is supported by the low levels of tissue VP1 found in this study. The high mortality levels observed in the more advanced stages of the disease may be the result of a combination of complex factors. The poor health of extensively starved and diseased clams may favour the proliferation of opportunistic bacteria (relatively high THBM levels in diseased clams) or other pathogenic agents which could lead to secondary infections and clam death.

Acknowledgements. The authors thank Dr M. Johnson for reviewing and correcting this paper. Research supported by the Commission of the European Communities (FAR Programme, contract number AQ-3-763). This paper is contribution no. 96003 of URA CNRS D1513

\section{LITERATURE CITED}

Arbuthnott JP, Smyth CJ (1977) Bacterial adhesion in host/pathogen interactions in animals. In: Ellwood DC, Melling J, Rutter P (eds) Adhesion of microorganisms to surfaces. Society for General Microbiology. Academic Press, New York, Special Publication 9:165-198

Bartkova G, Ciznar I (1992) Adherence of intestinal and extraintestinal Pseudomonas aeruginosa to tissue culture cells. Folia Microbiol 37(2):140-145

Chen D, Hanna PJ (1992) Attachement of Vibrio pathogens to cell of rainbow trout, Oncorhynchus mykiss (Walbaum) J Fish Dis 15:331-337 
Dungan CF, Elston RA (1988) Histopathological and ultrastructural characteristics of bacterial destruction of the hinge ligaments of cultured juvenile Pacific oysters, Crassostrea gigas. Aquaculture 72:1-14

Dungan CF, Elston RA, Schiewe MH (1989) Evidence for colonization and destruction of hinge ligaments in cultured juvenile Pacific oysters (Crassostrea gigas) by Cytophagalike bacteria. Appl Environ Microbiol 55(5):1128-1135

Elston RA, Elliott EL, Colwell RR (1982) Conchiolin infection and surface coating Vibrio: shell fragility, growth depression and mortalities in cultured oysters and clams (Crassostrea virginica, Ostrea edulis and Mercenaria mercenaria). J Fish Dis 5:265-284

Elston RA, Leibovitz L (1980) Pathogenesis of experimental vibriosis in larval American oysters, Crassostrea virginica. Can J Fish Aquat Sci 37:964-978

Friedman CS, Beattie JH, Elston RA, Hedrick RP (1991) Investigation of the relationship between the presence of a Gram-positive bacterial infection and summer mortality of the Pacific oyster, Crassostrea gigas. Thunberg Aquaculture $94: 1-15$

Friedman CS, Hedrick RP (1991) Pacific Oyster Nocardiosis isolation of the bacterium and induction of laboratory infections. J Invertebr Pathol 57:109-120

Gabe M (1968) Techniques histologiques. Masson \& Cie, Paris

Ijjima Y, Yamada $H$, Shinoda S (1981) Adherence of Vibrio parahaemolyticus and its relation to pathogenicity. Can J Microbiol 27:1252-1259

Le Pennec M, Prieur D (1977) Les antibiotiques dans les élevages de larves de bivalves marins. Aquaculture 12:15-30

Maes P (1992) Pathologie bactérienne chez deux invertébrés marins. La maladie des lesions vertes des échinides réguliers et la maladie de l'anneau brun de la palourde Ruditapes philippinarum. Thèse de doctorat, Université de Bretagne Occidentale, Brest

Nottage AS, Sinclair PD, Birkbeck TH (1989) Role of low-molecular-weight ciliostatic toxins in vibriosis of bivalve mollusks. J Aquat Anim Health 1:180-186

Oubella R, Maes P, Paillard C, Auffret M (1993) Experimentally induced variation in hemocytes density for Ruditapes philippinarum and $R$. decussatus (Mollusca, Bivalvia). Dis Aquat Org 15:193-197

Oubella R, Paillard C, Maes P. Auffret M (1994) Changes in hemolymph parameters in the Manila clam Ruditapes philippinarum (Mollusca, Bivalvia) following bacterial challenge. J Invertebr Pathol 64:33-39

Responsible Subject Editor: A. K. Sparks, Seattle, Washington, USA
Paillard C (1992) Etiologie et caractérisation de la maladie de l'anneau brun chez la palourde d'élevage Ruditapes philippinarum. Thèse de doctorat, Université de Bretagne Occidentale, Brest

Paillard C, Perclay L, Le Pennec M, Le Picard D (1989) Origine pathogène de l'anneau brun chez Tapes philippinarum (mollusque, bivalve). C R Acad Sci Paris 309(3): 235-241

Paillard C, Maes P (1990) Etiologie de la maladie de l'anneau brun chez Tapes philippinarum: pathogénicité d'un Vibrio sp. C R Acad Sci Paris 310(3):15-20

Paillard C. Maes P (1994) Brown ring disease in the Manila clam Ruditapes philippinarum: establishment of a classification system. Dis Aquat Org 19:137-146

Paillard C, Maes P (1995a) The brown ring disease in the Manila clam, Ruditapes philippinarum 1: Ultrastructural alterations of the periostracal lamina. J Invertebr Pathol 65:91-100

Paillard C, Maes $P$ (1995b) The brown ring disease in the Manila clam, Ruditapes philippinarum 2: Microscopic study of the brown ring syndrome. J Invertebr Pathol 65: $101-110$

Paillard C, Maes P, Oubella R (1994) Brown ring disease in clams. Ann Rev Fish Dis 4:1-22

Plana S (1995) Perturbations de la glande digestive et du métabolisme chez la palourde aquacole, Ruditapes philippinarum, affectée par la maladie de l'anneau brun. Thèse de doctorat, Université de Bretagne Occidentale, Brest

Plana S, Le Pennec M (1991) Altérations de la glande digestive et conséquences nutritionnelles chez la palourde Ruditapes philippinarum contaminée par une bactérie du genre Vibrio. Aquat Liv Resour 4:255-264

Rogers HJ (1977) Adhesion of microorganisms to surfaces: some general considerations of the role of the envelope. In: Ellwood DC, Melling J, Rutter P (eds) Adhesion of microorganisms to surfaces. Society for General Microbiology. Academic Press, New York, Special Publication 9. $29-53$

Smith H (1977) Microbial surfaces in relations to pathogenicity. Bacteriol Rev 41:475-500

Tubiash HS, Chanley PE, Leifson E (1965) Bacillary necrosis, a disease of larval and juvenile bivalve mollusk.s. J Bacteriol 90(4):1036-1044

Tubiash HS, Colwell RR, Sakazaki R (1970) Marine vibrios associated with bacillary necrosis, a disease of larval and juvenile bivalve mollusks. J Bacteriol 103(1):272-273

Manuscript first received: May 30, 1995

Revised version accepted: July 18, 1996 